\title{
Traditional treatment of epilepsy
}

\section{Trepanation revisited}

\section{Figure Destructive form of traditional epilepsy therapy}
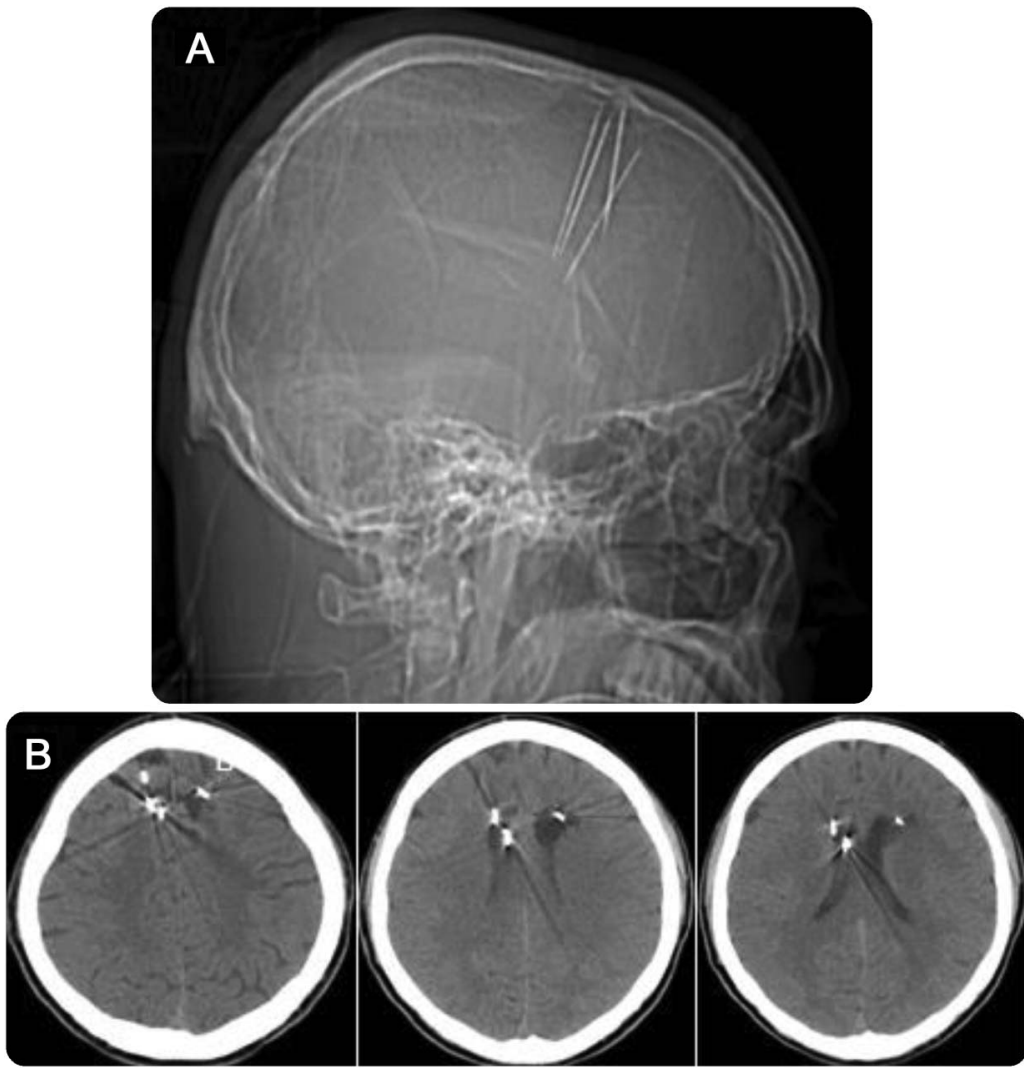

(A) Scout image of CT scan shows multiple metallic needles projecting from region of coronal suture into brain. (B) Axial brain images at brain window setting show needles in frontal lobes with surrounding low density indicating gliosis.

A 29-year-old South Asian man, with epilepsy since childhood, presented to the emergency room with a seizure. CT scan (figure) showed multiple metallic needles projecting from the coronal suture into the brain. In order to expel the demon that a traditional healer believed was haunting the patient, the skull and brain were pierced with needles. It is unclear whether the demon was successfully expelled, but the seizures persisted and could have been worsened by this treatment. Measures are warranted to warn the public against dangerous modes of traditional medicine. ${ }^{1,2}$

Yousef Mohammad, MD, MSc, Fawaz Al-Hussain, MD, MPH, Sajjad Hussain, MD, Khulood K. Al Raddadi From King Saud University, Riyadh, Saudi Arabia.

Author contributions: Y.M.: final drafting of the manuscript and reviewing the CT images. F.A.-H.: reviewing the manuscript draft and CT images. S.H.: interpreting the images and reviewing the manuscript draft. K.K.A.R.: providing the clinical details and reviewing the manuscript draft and CT images.

Study funding: Supported by college of medicine research center, Deanship of Scientific Research, King Saud University, Riyadh, Saudi Arabia.

Disclosure: The authors report no disclosures relevant to the manuscript. Go to Neurology.org for full disclosures.

Correspondence to Dr. Mohammad: ymohammad@ksu.edu.sa

1. Abou-Elhamd KE. Kaiy as traditional therapy for pain: is it helpful or a myth? J Laryngol Otol 2009;123:566-568.

2. Moon SH, Han HH, Rhie JW. Factitious panniculitis induced by cupping therapy. J Craniofac Surg 2011;22:2412-2414. 


\title{
Neurology
}

\author{
Traditional treatment of epilepsy: Trepanation revisited \\ Yousef Mohammad, Fawaz Al-Hussain, Sajjad Hussain, et al. \\ Neurology 2016;87;1064 \\ DOI 10.1212/WNL.0000000000003069
}

This information is current as of September 5, 2016

Updated Information \&
Services

References

Subspecialty Collections

Permissions \& Licensing

Reprints including high resolution figures, can be found at: http://n.neurology.org/content/87/10/1064.full

This article cites 2 articles, 0 of which you can access for free at: http://n.neurology.org/content/87/10/1064.full\#ref-list-1

This article, along with others on similar topics, appears in the following collection(s):

All Epilepsy/Seizures

http://n.neurology.org/cgi/collection/all_epilepsy_seizures All Ethics in Neurology/Legal issues http://n.neurology.org/cgi/collection/all_ethics_in_neurology_legal_iss ues

Brain trauma

http://n.neurology.org/cgi/collection/brain_trauma CT

http://n.neurology.org/cgi/collection/ct

Patient safety

http://n.neurology.org/cgi/collection/patient_safety

Information about reproducing this article in parts (figures,tables) or in its entirety can be found online at:

http://www.neurology.org/about/about_the_journal\#permissions

Information about ordering reprints can be found online:

http://n.neurology.org/subscribers/advertise

Neurology ${ }^{\circledR}$ is the official journal of the American Academy of Neurology. Published continuously since 1951, it is now a weekly with 48 issues per year. Copyright @ 2016 American Academy of Neurology. All rights reserved. Print ISSN: 0028-3878. Online ISSN: 1526-632X.

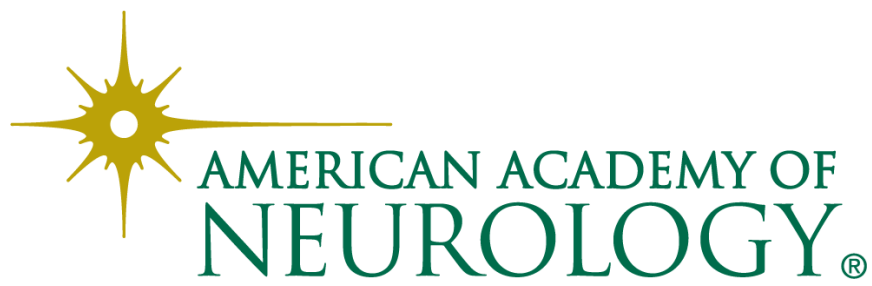

